\title{
LAJU PENGOSONGAN ISI PERUT PADA IKAN KERAPU CANSIR (Epinephelus fuscoguttatus $x$ Epinephelus corallicola) SEBAGAI INFORMASI AWAL DALAM PENENTUAN MANAJEMEN PEMBERIAN PAKAN
}

\author{
Daniar Kusumawati dan Suko Ismi \\ Balai Besar Penelitian dan Pengembangan Budidaya Laut \\ Jl. Br. Gondol Kec. Gerokgak Kab. Buleleng, Kotak Pos 140, Singaraja, Bali 81101 \\ E-mail: ornamental_research@yahoo.co.id
}

(Naskah diterima: 11 April 2014; Revisi final: 2 Oktober 2014;

Disetujui publikasi: 10 November 2014)

\begin{abstract}
ABSTRAK
Informasi mengenai laju pengosongan isi perut suatu jenis ikan sangat diperlukan untuk meningkatkan keefektifan dan keefisienan pemanfaatan pakan. Dalam penelitian ini dilakukan uji untuk mengetahui lama pengosongan isi perut benih kerapu cansir yaitu hibrida dari kerapu macan (Epinephelus fuscoguttatus) $x$ kerapu pasir (Epinephelus corallicola) terhadap jenis pakan pelet. Benih kerapu cansir sejumlah 50 ekor dengan kisaran panjang 8,00 $\pm 0,76 \mathrm{~cm}$ terlebih dahulu dipuasakan selama 48 jam dan kemudian ikan diberi makan secara adlibitum. Ikan selanjutnya dibedah sejumlah lima ekor pada jam ke-0, 6, 12, 15, 18, 21 , 24, 30, 35, dan 42. Berdasarkan hasil pengamatan diketahui bahwa lama pengosongan isi perut berdasarkan persentase derajat kepenuhan isi perut per satuan waktu (ISC) pada ikan kerapu cansir ukuran 8,00 $\pm 0,76 \mathrm{~cm}$ terhadap jenis pakan pelet mencapai 28 jam dengan total laju kecepatan pengosongan lambung rata-rata terhadap penurunan persentase pakan sebesar 2,9\%/jam. Berdasarkan lama pengosongan isi perutnya, ikan kerapu cansir cukup diberikan pakan pelet dengan frekuensi satu kali per hari.
\end{abstract}

KATA KUNCl: kerapu cansir, laju pengosongan isi perut, manajemen pakan

ABSTRACT: Gastric evacuation rate of cansir grouper (Epinephelus fuscoguttatus $x$ Epinephelus corallicola) for basic information in determination feeding management. By: Daniar Kusumawati and Suko Ismi

Information about fish gastric evacuation rate is important to improve the effectiveness and efficiency of feed utilization. Thus, this research was conducted to find out duration of gastric evacuation rate of cansir grouper juveniles (a hybrid of tiger grouper (Epinephelus fuscoguttatus) $X$ spotted grouper (Epinephelus corallicola)) for artificial feed. Previously, fishes were fasted for 48 hours and then fishes were fed ad libitum. Furthermore, five fishes were dissected at $0^{\text {th }}, 6^{\text {th }}, 12^{\text {th }}, 15^{\text {th }}$, $18^{\text {th }}, 21^{\text {st }}, 24^{\text {th }}, 30^{\text {th }}, 35^{\text {th }}$, and $42^{\text {nd }}$ hours after feeding. The result shown that gastric evacuation rate based on index of stomach content (ISC) of cansir grouper juveniles size of $8.00 \pm 0.76 \mathrm{~cm}$ in length was reached at 28 hours after feeding and the average of gastric evacuation rate was $2.9 \%$ /hours. Based on gastric evacuation rate, feeding frequency for cansir grouper juveniles was suggested once a day.

KEYWORDS: cansir grouper, gastric evacuation rate, feeding management 


\section{PENDAHULUAN}

Kerapu cansir merupakan ikan kerapu hibrid hasil persilangan antara kerapu macan (Epinephelus fuscoguttatus) $\mathrm{x}$ kerapu pasir (Epinephelus corallicola). Informasi mengenai asupan makanan yang optimal untuk kegiatan pembesaran benih kerapu cansir masih belum diketahui. Ketersediaan pakan merupakan salah satu faktor penting bagi pertumbuhan dan sintasan ikan. Jumlah kebutuhan pakan pada setiap ikan sangat berkaitan erat dengan bobot dan umur ikan, serta faktor kondisi lingkungan. Pakan yang dikonsumsi ikan tidak semuanya digunakan untuk pertumbuhan. Sebagian besar energi dari makanan digunakan untuk metabolisme, dan sebagian digunakan untuk aktivitas, dan reproduksi (Brett \& Groves, 1979).

Pakan yang dikonsumsi ikan akan melalui proses pencernaan yaitu suatu proses penyederhanaan makanan melalui mekanisme fisik dan kimiawi sehingga menjadi bahan yang mudah diserap dan diedarkan ke seluruh tubuh melalui sistem peredaran darah. Laju cerna pada setiap jenis ikan berbeda-beda dipengaruhi oleh kondisi lingkungan dan jenis makanan yang dikonsumsi (Gerald, 1973), serta hormonal (Rønnestad et al., 2007). Semakin tinggi laju cerna ikan terhadap makanan akan mempercepat pengosongan lambung sehingga asupan kebutuhan makanan pada ikan tersebut juga tinggi. Dari proses cerna akan diperoleh energi yang sebagian dipergunakan untuk keperluan metabolisme. Kelebihan energi yang dihasilkan dari proses metabolisme di antaranya akan disimpan dalam bentuk daging untuk pertumbuhan. Kebutuhan dan kemampuan memanfaatkan sumber energi pada setiap organisme berbeda-beda. Dapat dikatakan bahwa pertumbuhan ikan sangat ditentukan oleh besarnya sumber nutrisi dalam pakan.

Melalui estimasi laju cerna atau laju pengosongan isi perut pada benih ikan kerapu cansir dapat dijadikan tolok ukur untuk pemberian pakannya. Pada dasarnya informasi mengenai laju cerna suatu jenis ikan sangat diperlukan untuk meningkatkan keefektifan dan keefisienan pemanfaatan pakan. Penelitian ini bertujuan untuk mengetahui lama pengosongan isi perut benih kerapu cansir terhadap pakan pelet sebagai dasar informasi dalam penentuan manajemen pemberian pakan.

\section{BAHAN DAN METODE}

Ikan cansir yang digunakan dalam penelitian sejumlah 50 ekor berukuran panjang $8,00 \pm 0,76 \mathrm{~cm}$. Ikan dipelihara dalam bak kerucut kapasitas $150 \mathrm{~L}$ dengan sistem air mengalir. Sebelum digunakan dalam percobaan, ikan dipuasakan selama 48 jam (dua hari) untuk memastikan kondisi lambung pada benih ikan telah kosong seluruhnya. Kemudian ikan diberi pakan pelet komersil dengan frekuensi satu kali pada pagi hari secara adlibitum. Estimasi jumlah pakan yang dikonsumsi ditentukan dari selisih antara pakan yang diberikan dengan sisa pakan yang tidak dimakan. Untuk mengetahui pola laju cerna dilakukan pengambilan sampel sejumlah lima ekor ikan pada jam ke-0 yaitu sesaat setelah pemberian pakan, ke-6, 12, 15, 18, 21 , $24,30,35$, dan 42 setelah pemberian pakan. Sampel ikan dibedah untuk diambil saluran pencernaannya mulai dari esophagus hingga anus, untuk kemudian dilakukan penimbangan dan pengamatan terhadap kondisi saluran pencernaan.

Tingkat kepenuhan isi perut (Index of stomach content (ISC)) diidentifikasikan sebagai indikator dalam menentukan aktivitas makan ikan per satuan waktu yang diestimasi dalam perbandingan antara bobot pakan dalam saluran cerna dan bobot saluran cerna (Hyslop, 1980). Persentase perubahan chyme menjadi kimus diperoleh berdasarkan estimasi selisih ISC pada jam ke-0 dengan ISC pada jam di mana kondisi usus mulai terdapat kimus. Sementara itu, laju kecepatan pengosongan isi perut diestimasikan berdasarkan selisih ISC pada t-0 dengan ISC pada t-i dibagi waktu pemberian pakan $(\Delta \mathrm{ISC} / \Delta \mathrm{t})$. Pada analisis korelasi dilakukan dengan menghubungkan dua data dengan menggunakan fasilitas trendline (regression type) pada Microsoft excel.

\section{HASIL DAN BAHASAN}

Berdasarkan perhitungan jumlah pemberian pakan secara adlibitum pada benih kerapu cansir (Epinephelus fuscoguttatus $\mathrm{x}$ Epinephelus corallicola), diketahui bahwa persentase jumlah pakan yang dikonsumsi sebesar 11,68\% dari bobot badan. Sementara itu, pada beberapa spesies ikan yang lain yaitu pada ikan kakap merah dengan ukuran panjang rata-rata yang sama diketahui memiliki persentase konsumsi pakan sebesar 1,8\% (Aslianti et al., 2009) dan pada ikan kerapu pa- 
sir dengan bobot rata-rata yang sama memiliki persentase konsumsi pakan 2,71\% dari bobot badannya berdasarkan tingkat kekenyangannya (Sutarmat, 2008). Nampaknya pada ikan kerapu cansir yang merupakan hasil perkawinan silang antara kerapu macan dan kerapu pasir ini mengonsumsi pakan dalam jumlah yang relatif lebih banyak dibandingkan kerapu pasir (populasi asal). Ikan-ikan hasil perkawinan silang (hibrida) pada umumnya memiliki performa yang lebih cepat tumbuh dibandingkan dengan populasi asal (Ismi et al., 2013). Berdasarkan status energetiknya, diketahui bahwa umumnya ikan-ikan hasil perkawinan silang memiliki respons yang tinggi terhadap makanan dan jauh lebih tinggi dari populasi asal sehingga energi yang tersedia cukup besar tersebut digunakan untuk pertumbuhan (Tuncer et al., 1990).

Pembedahan dilakukan untuk melihat kondisi isi perut pada saluran pencernaan ikan cansir mulai dari esophagus hingga anus. Hasil pembedahan benih ikan cansir menunjukkan bahwa pada enam jam setelah pemberian pakan nampak pakan masih terlihat utuh dan belum tercerna (Tabel 1). Proses cerna terjadi pada kisaran waktu 12 jam di mana terlihat dari bentuk pakan yang awalnya masih berbentuk butiran pelet sejumlah $7 \%$ berubah menjadi hancur (chyme). Hingga jam ke-18, kondisi usus nampak masih kosong karena belum nampak adanya chyme yang memasuki usus. Pada jam ke-21, mulailah nampak chyme memenuhi usus atau dikenal dengan istilah kimus. Pakan yang dimakan oleh ikan masuk ke dalam lambung masih dalam bentuk gumpalan padatan yang kemudian diproses (dicerna) sehingga berbentuk bubur yang disebut chyme. Otot lambung yang tebal berfungsi untuk mengaduk dan menggerus makanan di dalamnya, serta mencampurnya secara sempurna dengan getah/sekret pencernaan yang dikeluarkan oleh lambung. Chyme lalu disalurkan ke usus halus (Fänge \& Grove, 1979).

Berdasarkan kondisi lambung dan usus, menunjukkan bahwa lambung benih kerapu cansir memerlukan waktu 21 jam untuk merubah gumpalan pakan pelet menjadi chyme dan selanjutnya chyme yang telah bercampur dengan getah lambung yang disebut kimus akan memasuki usus. Berdasarkan data tersebut dapat diketahui persentase pakan padat yang mampu dirubah menjadi chyme sebesar 55,55\% untuk kemudian chyme dapat masuk ke dalam usus (kimus) dan terjadi proses penyempurnaan penyerapan sari makanan. Nampaknya pada benih ikan cansir, proses perubahan makanan pelet dalam bentuk padatan hingga menjadi kimus memerlukan waktu yang cukup lama apabila dibandingkan dengan benih ikan kakap pada ukuran yang sama hanya memerlukan waktu sekitar enam jam (Aslianti et al., 2009). Laju cerna pada suatu spesies sangat berkorelasi dengan laju metabolisme sebagai proses untuk menghasilkan energi. Laju metabolisme itu sendiri sangat dipengaruhi oleh suhu lingkungan, pola aktivitas ikan, dan ukuran ikan (Winberg, 1960). Pada ikan kakap dengan ukuran badan dan kondisi suhu air pemeliharaan yang relatif sama yaitu $28^{\circ} \mathrm{C}$ memiliki laju cerna yang lebih cepat jika dibandingkan dengan ikan kerapu cansir. Hal ini terkait dengan pola aktivitas (tingkah laku) ikan kakap yang merupakan jenis ikan pelagis aktif. Sementara itu, pada ikan kerapu cansir, pola aktivitasnya sama dengan ikan kerapu yang lain di mana cenderung berada di dasar dan pasif. Pada ikan-ikan yang memiliki aktivitas tinggi memerlukan energi yang cukup besar sehingga ritme internal di dalam tubuhnya juga ikut menyesuaikan untuk memenuhi kebutuhan energi tersebut (Mujiman, 1984). Sementara itu, pada ikan-ikan dengan aktivitas pasif tidak memerlukan energi yang cukup besar dalam waktu singkat, sehingga laju metabolismenya cenderung lambat yang tentunya akan berdampak terhadap kecepatan laju cernanya yang juga semakin lambat. Kebutuhan akan energi pada masing-masing spesies ikan berbeda. Sinyal akan kebutuhan energi tersebut diteruskan pada lambung agar lambung melakukan proses cerna.

Kimus berada pada usus mulai dari jam ke-21 hingga jam ke-28 bila mengacu pada korelasi derajat kepenuhan lambung dengan lama waktu pengosongan lambung (Gambar 2). Jadi waktu yang diperlukan usus untuk menyerap sari pati makanan adalah \pm 7 jam, untuk kemudian sisa makanan dibuang berupa feses. Pada benih ikan kakap proses penyerapan kimus di dalam usus memerlukan waktu enam jam (Aslianti et al., 2009), tidak jauh berbeda pada benih kerapu cansir. Nampaknya proses penyerapan kimus di dalam usus tidak memerlukan waktu yang cukup lama dan berlangsung dalam kurun waktu yang relatif sama.

Penurunan persentase derajat kepenuhan lambung (ISC) pada ikan cansir cukup lambat. Laju kecepatan pengosongan isi perut pada 
Tabel 1. Data pengamatan laju cerna benih kerapu cansir

Table 1. Observation data on digestion rate of cansir grouper jeveniles

\begin{tabular}{|c|c|c|c|c|}
\hline $\mathbf{T}$ & W1 & W2 & ISC (\%) & Ket erangan (Remark) \\
\hline 0 & 2.045 & 1.647 & 80.54 & $\begin{array}{l}\text { Pakan masih utuh, lambung penuh, usus kosong } \\
\text { The feed was still in a solid form in the gastric, the } \\
\text { intestine was empty }\end{array}$ \\
\hline 6 & 1.747 & 1.256 & 71.89 & $\begin{array}{l}\text { Pakan masih utuh, lambung penuh, usus kosong } \\
\text { The feed was still in a solid form in the gastric, the } \\
\text { intestine was empty }\end{array}$ \\
\hline 12 & 1.410 & 0.943 & 66.86 & $\begin{array}{l}\text { Pakan masih utuh di lambung, sedikit sudah hancur, } \\
\text { usus kosong } \\
\text { Most part of the feed was still in a solid form but a } \\
\text { small part has been crumbled, the intestine was empty }\end{array}$ \\
\hline 15 & 1.067 & 0.576 & 53.97 & $\begin{array}{l}\text { Pakan sebagian masih utuh, sebagian sudah hancur di } \\
\text { lambung, usus kosong } \\
\text { Most part of the feed was still in a solid form but a } \\
\text { small part has been crumbled, the intestine was empty }\end{array}$ \\
\hline 18 & 1.053 & 0.562 & 53.39 & $\begin{array}{l}\text { Pakan sebagian masih utuh, sebagian sudah hancur di } \\
\text { lambung, usus kosong } \\
\text { Half part of the feed was still solid and half the other } \\
\text { part has been crumbled, intestine was empty }\end{array}$ \\
\hline 21 & 0.753 & 0.270 & 35.80 & $\begin{array}{l}\text { Pakan di lambung sebagian sudah hancur dan sebagian } \\
\text { pakan yang tercerna mulai memasuki usus } \\
\text { Most part of the feed have been crumbled and some } \\
\text { entering the intestine }\end{array}$ \\
\hline 24 & 0.657 & 0.166 & 25.24 & $\begin{array}{l}\text { Lambung hampir kosong, pakan yang tercerna sudah } \\
\text { me masuki usus } \\
\text { The gastric was almost empty, mainly feed have } \\
\text { entered the intestine }\end{array}$ \\
\hline 30 & 0.398 & 0 & 0 & $\begin{array}{l}\text { Lambung kosong, usus kosong } \\
\text { The gastric was empty, the intestine was empty }\end{array}$ \\
\hline
\end{tabular}

Keterangan (Note):

$\mathrm{T} \quad=$ Waktu setelah pemberian pakan (jam) (Time after feeding (hours))

$\mathrm{W} 1$ = Bobot saluran pencernaan berisi pakan (Weight of digestive tract with feed inside) $(\mathrm{g})$

$\mathrm{W} 2$ = Bobot pakan dalam saluran pencernaan (Feed weight in digestive tract) $(\mathrm{g})$

ISC = Tingkat kepenuhan isi perut (Index of stomach content) (\%)

12 jam setelah pemberian pakan berkisar $1,14 \% / j a m$. Memasuki jam ke-15, laju kecepatan cerna terhadap persentase pakan dalam usus meningkat menjadi 4,29\%/jam. Saat memasuki jam ke-18, kecepatan penurunan persentase pakan sangat lambat yaitu berkisar 0,19\%/jam. Memasuki jam ke-21 kecepat- an cerna terhadap pakan dalam perut meningkat kembali menjadi 5,86\%/jam dan relatif menurun berturut-turut pada tiga jam berikutnya menjadi 3,52\%/jam (jam ke-24) dan $4,21 \% / j a m$ hingga lambung kosong (jam ke30). Nampaknya kecepatan pengosongan isi perut benih ikan kerapu cansir pada tiap wak- 
tu terhadap jenis pakan pelet berbeda-beda. Sesungguhnya hal tersebut menunjukkan bahwa kecepatan pengosongan lambung diatur oleh sinyal dari syaraf perut di mana melalui mekanisme yang kompleks bertugas untuk mengontrol pengosongan kimus pada kecepatan yang tidak melebihi kecepatan kimus dicerna dan diabsorbsi dalam usus (Steven \& Hume, 1996).

Pada dasarnya, pengosongan lambung dipermudah oleh gelombang peristaltik pada antrum lambung, dan dihambat oleh resistensi pilorus terhadap jalan makanan. Gelombang peristaltik pada antrum, bila aktif, secara khas terjadi hampir pasti tiga kali per menit, menjadi sangat kuat dekat insisura angularis, dan berjalan ke antrum, kemudian ke pylorus, dan akhirnya ke duodenum. Ketika gelombang berjalan ke depan, pyloric sphincter, dan bagian proksimal duodenum dihambat, yang merupakan relaksasi reseptif. Pada setiap gelombang peristaltik, beberapa millimeter kimus didorong masuk ke duodenum. Derajat aktivitas pompa pilorus diatur oleh sinyal dari lambung sendiri dan juga oleh sinyal dari duodenum. Sinyal dari lambung adalah derajat peregangan lambung oleh makanan, dan adanya hormon gastrin yang dikeluarkan dari antrum lambung akibat respons regangan. Kedua sinyal tersebut mempunyai efek positif meningkatkan daya pompa pilorus dan karena itu mempermudah pengosongan lambung. Sebaliknya, sinyal dari duodenum menekan aktivitas pompa pilorus. Pada umumnya, bila volume kimus berlebihan atau kimus tertentu berlebihan telah masuk duodenum. Sinyal umpan balik negatif yang kuat, baik syaraf maupun hormonal dihantarkan ke lambung untuk menekan pompa pilorus. Jadi, mekanisme ini memungkinkan kimus masuk ke duodenum hanya secepat ia dapat diproses oleh usus halus (Steven \& Hume, 1996).

Kecenderungan pola nilai ISC terhadap lama pengosongan lambung mengikuti hubungan korelasi polynomial $y=-0,0009 x^{2}+$ $0,001 x+0,7552$ dengan nilai $R^{2}=0,986$ (Gambar 1). Berdasarkan pola laju cerna pada ikan kerapu cansir, dapat diperkirakan saat kondisi perut kosong sempurna terjadi pada jam ke-28. Nampaknya ikan kerapu cansir merupakan jenis ikan dengan laju cerna rendah terhadap jenis pakan pelet. Berbeda dengan benih ikan kakap merah (Lutjanus sebae) pada ukuran yang sama hanya memerlukan waktu selama 18 jam untuk mencer- na pakan yang diberikan secara ad libitum hingga kondisi usus benar-benar kosong (Aslianti et al., 2009). Laju cerna pada ikan sangat berkaitan dengan respons pakan. Kedua jenis ikan tersebut memiliki respons pakan yang berbeda di mana pada ikan kakap merah hanya mengonsumsi sebesar 1,8\% dari bobot badan sementara ikan kerapu cansir mengonsumsi sebesar $11,68 \%$ dari bobot badan. Setiap ikan memiliki bentuk dan ukuran lambung yang berbeda-beda. Derajat kepenuhan lambung pada ikan akan berbeda, tergantung dari bobot, panjang, dan bentuk lambung. Ketika individu ikan memberikan respons yang cukup tinggi terhadap pakan akan meningkatkan kuantitas pakan yang dikonsumsi dan hal ini memperlambat laju cerna pada ikan (Smith, 1989). Sementara itu, laju cerna makanan (persentase bobot pakan yang mampu dikonsumsi per satuan waktu) sangat bergantung pada suhu media pemeliharaan (Gerald, 1973; Ryer \& Boehlert, 1983; Parrish \& Margraf, 1990; Pääkkönen \& Marjomäki, 1997; Hurst, 2004), frekuensi pemberian pakan (Riche et al., 2004; Jackson et al., 2007) dan ukuran pakan (Garber, 1983; Pääkkönen et al., 1999), serta ukuran ikan (Sutarmat, 2008). Namun untuk faktor ukuran pakan dan ukuran ikan masih terdapat kontroversi karena pada beberapa jenis ikan yang lain ukuran pakan maupun ikan tidak memberikan pengaruh secara signifikan apapun terhadap laju cerna (Gerald, 1973; Bromley, 1994; Andersen, 1999). Faktor tersebut di atas merupakan stimulus lingkungan yang diterima oleh syaraf otak untuk kemudian diteruskan kepada syaraf perut sehingga proses cerna makanan di dalam perut dapat berlangsung. $\mathrm{Di}$ dalam perut proses cerna berlangsung akibat adanya motilitas gastrointestinal dengan mekanisme yang kompleks di mana melibatkan aktivitas enzim dan hormon (Fänge \& Grove, 1979).

Berdasarkan derajat kepenuhan lambung (ISC), ikan kerapu cansir dapat diberikan pakan pelet satu kali per hari dengan asumsi dalam kurun waktu 24 jam dalam lambung masih terdapat sisa pakan yang belum tercerna sebesar $25,24 \%$. Pada kondisi tersebut lambung tidak benar-benar kosong, terdapat sisa makanan untuk dicerna dan diabsorbsi tubuh sebagai energi. Frekuensi pemberian pakan satu kali dalam sehari mungkin dapat dirasa ideal bila dikaitkan dengan strategi manajemen pemberian pakan sebagai upaya memaksimalkan respons ikan terhadap pakan karena pengo- 


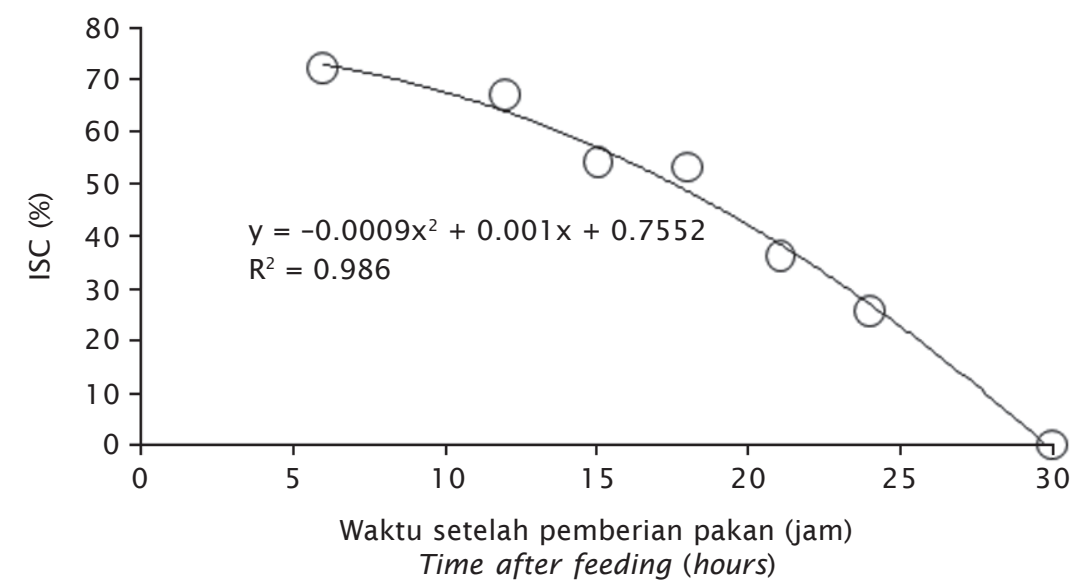

Gambar 1. Pola laju cerna berdasarkan Index of stomach content (ISC)

Figure 1. Digestion rate pattern based on Index of stomach content (ISC)
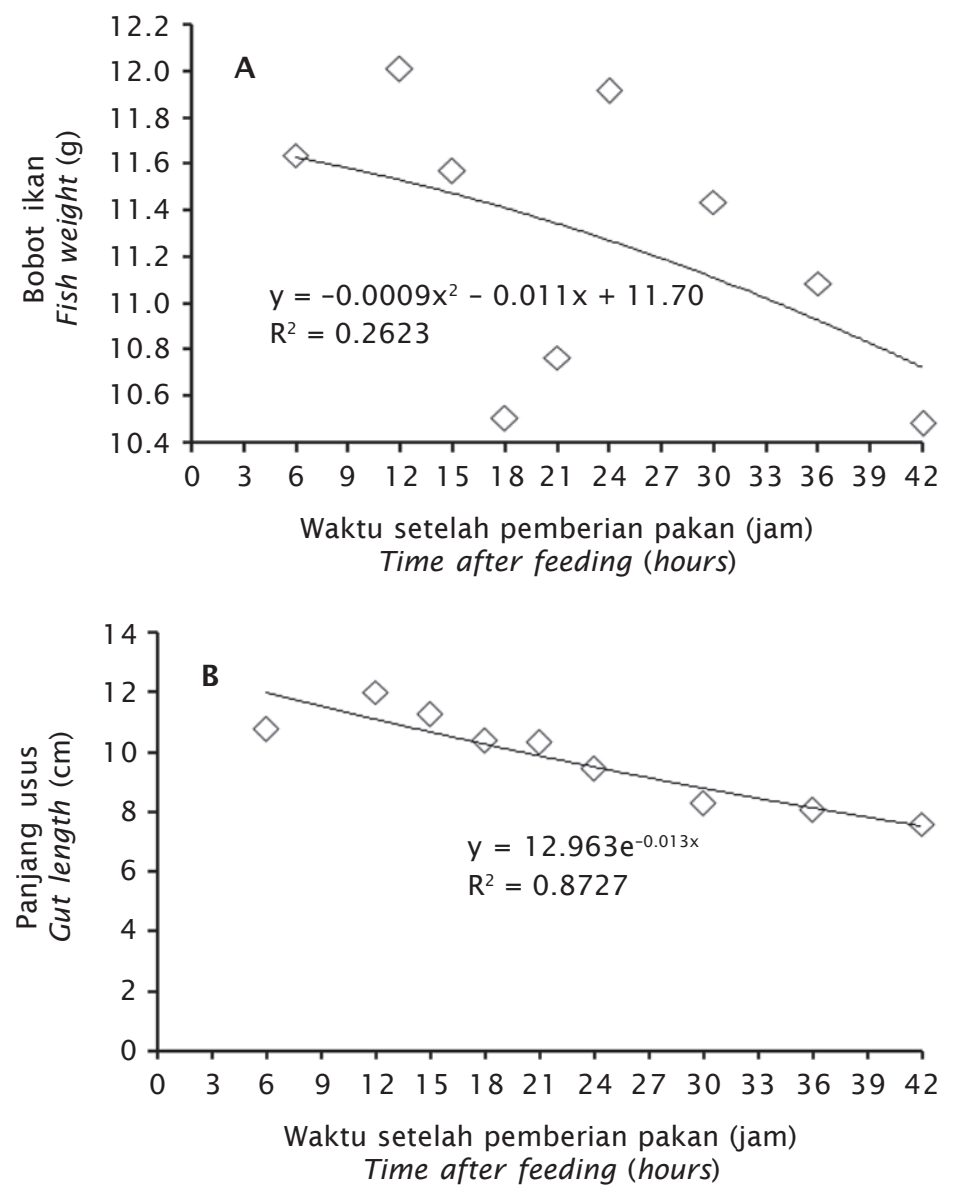

Gambar 2. Korelasi laju cerna dengan bobot ikan (A) dan panjang usus (B)

Figure 2. Correlation of digestion rate with fish weight (A) and gut length (B) 
songan lambung sangat berkaitan dengan respons tersebut. Ikan akan memiliki respons makan yang lebih baik ketika lambung dalam kondisi hampir kosong (pemuasaan) apabila dibandingkan ikan yang diberi makan terusmenerus (tanpa pemuasaan) (Smith, 1989). Diketahui pula dengan strategi pemuasaan pada ikan akan meningkatkan efisiensi pakan yang jauh lebih baik dengan laju pertumbuhan yang sama dengan ikan yang diberi makan secara periodik setiap hari (Yuwono et al., 2005). Namun asumsi tersebut belum dapat dijadikan tolok ukur untuk memacu pertumbuhan karena frekuensi pemberian pakan juga akan memengaruhi laju cerna dan pertumbuhan ikan (Lee et al., 2000; Jackson et al., 2007).

Waktu setelah pemberian pakan yang terkait dengan persentase derajat kepenuhan isi perut per satuan waktu diketahui memberikan korelasi yang erat terhadap elastisitas panjang usus tetapi tidak terhadap bobot ikan (Gambar 2). Berdasarkan nilai $\mathrm{R}^{2}$ antara waktu setelah pemberian pakan terhadap bobot ikan yang sangat kecil yaitu 0,2623 menunjukkan bahwa keduanya tidak saling berkorelasi. Sebaliknya, seiring dengan lama laju cerna ikan, elastisitas panjang usus akan semakin memendek mengikuti persamaan eksponensial $y=12,963 \mathrm{e}^{-0,013 x}$ dengan nilai $\mathrm{R}^{2}=$ 0,8727 . Usus sangat elastis di mana ketika dalam kondisi penuh dengan makanan maka usus ikut mengembang menyesuaikan jumlah pakan yang masuk dan ketika dalam keadaan kosong maka usus kembali mengerut (mengecil). Namun kondisi memendeknya usus tidak akan semakin kecil mengikuti semakin lama laju cerna karena usus memiliki panjang normal saat kondisi kosong. Oleh karena itu, hubungan laju cerna dengan panjang usus berkorelasi secara eksponensial yang artinya pada suatu titik optimum panjang usus akan relatif sama meskipun laju cerna semakin lama.

\section{KESIMPULAN}

Lama pengosongan isi perut berdasarkan persentase derajat kepenuhan isi perut per satuan waktu (ISC) pada ikan cansir ukuran $8,00 \pm 0,76 \mathrm{~cm}$ terhadap jenis pakan pelet mencapai 28 jam dengan total laju kecepatan pengosongan lambung rata-rata terhadap penurunan persentase pakan sebesar 2,9\%/ jam. Berdasarkan lama pengosongan isi perutnya, ikan cansir cukup diberikan pakan pelet dengan frekuensi satu kali per hari.

\section{DAFTAR ACUAN}

Andersen, N.G. (1999). The effects of predator size, temperature, and prey characteristics on gastric evacuation in whiting. Journal of Fish Biology, 54, 287-301.

Aslianti, T., Afifah, \& Kusumawati, D. (2009). Penentuan frekuensi pemberian pakan pada beberapa ukuran benih ikan kakap merah, Lutjanus sebae berdasarkan pengamatan tingkat laju cerna. Prosiding Seminar Nasional Biologi XX dan Kongres Perhimpunan Biologi Indonesia XIV, p. 826831.

Brett, J.R., \& Groves, T.D.D. (1979). Physiological energetic, In Fish physiology. Hoar, W.S., Randall, D.J., \& Brett, J.R. (Eds.). Academic Press. New York, 8, 279-352.

Bromley, P. (1994). The role of gastric evacuation experiments in quantifying the feeding rates of predatory fish. Review articles, Fish Biology and Fisheries, 4, 36-66.

Fänge, R., \& Grove, D. (1979). Digestion. In Fish physiology. Hoar, W.S., Randall, D.J., \& Brett, J.R. (Eds.). Academic Press. Academic Press. New York, 8, 162-260.

Garber, K.J. (1983). Effect of fish size, meal size and dietary moisture on gastric evacuation of pelleted diets by Yellow Perch, Perca flavescens. Aquaculture, 34, 41-49.

Gerald, V.M. (1973). Rate of digestion in Ophiocephalus punctatus Bloch. Comparative Biochemistry and Physiology, 46, 195205.

Hurst, T.P. (2004). Temperature and state-dependence of feeding and gastric evacuation in juvenil Pacific halibut. Journal of Fish Biology, 65, 157-169.

Hyslop, E.J. (1980). Stomach contents analysis-a review of methods and their application. Journal Fish Biology, 17(41), 1-429.

Ismi, S., Asih, Y.N., \& Kusumawati, D. (2013). Peningkatan produksi dan kualitas benih kerapu dengan program hibridisasi. Laporan Teknis Kegiatan Tahun 2012. Balai Besar Penelitian dan Pengembangan Budidaya Laut.

Jackson, S.J., Leahy, F.E., Jebb, S.A., Prentice, A.M., Coward, W.A., \& Bluck, L.J.C. (2007). Frequent feeding delays the gastric emptying of a subsequent meal. Appetite, 48, 199-205.

Lee, S.M., Hwang, U.G., \& Cho, S.H. (2000). Effects of feeding frequency and dietary moisture content on growth, body compo- 
sition and gastric evacuation of juvenil Korean rockfish (Sebastes schlegeli). Aquaculture, 187, 399-409.

Mujiman, A. (1984). Makanan ikan. Penebar Swadaya. Jakarta, $190 \mathrm{hlm}$.

Pääkkönen, J.P.J., Myyrä, R., \& Marjomäki, T.J. (1999). The effect of meal size on the rate of gastric evacuation of burbot, Lota lota (L.). Ecology of Freshwater Fish, 8, 19-54.

Pääkkönen, J.P.J., \& Marjomäki, T.J. (1997). Gastric evacuation rate of burbot fed singlefish meals at different temperatures. Journal of Fish Biology, 50, 555-563.

Parrish, D.L., \& Margraf, F.J. (1990). Gastric evacuation rates of white perch, Morone americana, determined from laboratory and field data. Environmental Biology of Fishes, 29, 155-158.

Riche, M., Haley, D.I., Oetker, M., Garbrecht, S., \& Garling, D.L. (2004). Effect of feeding frequency on gastric evacuation and the return of appetite in tilapia Oreochromis niloticus (L.). Aquaculture, 234, 657-673.

Rønnestad, I., Kamisaka, Y., Conceição, L.E.C., Morais, S., \& Tonheim, S.K. (2007). Digestive physiology of marine fish larvae: Hormonal control and processing capacity for proteins, peptides and amino acids. Aquaculture, 268, 82-97.

Ryer, C.H., \& Boehlert,G.W. (1983). Feeding chronology, daily ration, and the effects of temperature upon gastric evacuation in the pipefish, Syngnathus fuscus. Environmental Biology of Fishes, 9, 301-306.

Smith, L.S. (1989). Digestive functions in teleost fishes. Fish Nutrition $2^{\text {nd }}$. Academic Press Inc. p. 331-421.

Stevens, C.E. \& Hume, I.D. (1996). Comparative physiology of the vertebrate digestive system, $2^{\text {nd }}$ Eds. Cambridge University Press. New York, 400 pp.

Sutarmat, T. (2008). Pengaruh perbedaan ukuran ikan terhadap konsumsi pakan dan laju pengosongan lambung pada ikan kerapu pasir (Epinephelus corallicola). Prosiding Seminar Nasional Biodiversitas II. hlm. 183-191.

Tuncer, H., Harrel, R.M., \& Houde, E.D. (1990). Comparative energetics of striped bass (Morone saxatilis) and Hybrid (M. saxatilis x M. chrysops) juveniles. Aquaculture, 86, 387-400.

Winberg, G.G. (1960). Rate of metabolisme and food requirement of fishes. Fisheries $R e$ search Board of Canada Translation, 194, $202 \mathrm{pp}$.

Yuwono, E., Sukardi, P., \& Suliatyo, I. (2005). Konsumsi dan effisiensi pakan pada ikan kerapu bebek (Cromileptes altivelis) yang dipuasakan secara periodik. Berkala Penelitian Hayati, 10, 129-132. 